\title{
Electrical Properties of the Rabbit Cortical Collecting Duct from Obstructed and Contralateral Kidneys after Unilateral Ureteral Obstruction
}

\author{
Shigeaki Muto, Yukio Miyata, and Yasushi Asano \\ Department of Nephrology, Jichi Medical School, Minamikawachi, Kawachi, Tochigi, 329-04 Japan
}

\begin{abstract}
Electrophysiological techniques were used to determine the electrical properties of the collecting duct $(\mathrm{CD})$ cell in the isolated cortical collecting duct from obstructed $\left(\mathrm{UUO}_{\mathrm{OK}}\right)$ and contralateral ( $U U O_{C K}$ ) kidneys in rabbits $24 \mathrm{~h}$ after unilateral ureteral obstruction (UUO); results were compared with those from sham-operated kidneys. The lumen-negative transepithelial voltage and the basolateral membrane voltage $\left(V_{B}\right)$ were decreased in the $\mathrm{UUO}_{\mathrm{OK}}$, and increased in the $U \mathrm{UO}_{\mathrm{CK}}$. The transepithelial conductance $\left(G_{T}\right)$ was decreased in parallel with an increase in the fractional apical membrane resistance $\left(f R_{A}\right)$ and a decrease in apical membrane conductance in the UUO $O_{O K}$. By contrast, the $G_{T}$ was increased in parallel with increases in apical and basolateral membrane conductances in the $\mathrm{UUO}_{\mathrm{CK}}$. The amiloride-sensitive changes in apical membrane voltage $\left(V_{A}\right), G_{T}$ and $f R_{A}$ were lower in the $U U O_{O x}$, but greater in the $U U O_{C K}$. The changes in $V_{A}$ and $G_{T}$ upon raising the perfusate $\mathrm{K}^{+}$concentration and upon addition of luminal $\mathrm{Ba}^{2+}$ were decreased in the $\mathrm{UUO}_{\mathrm{OK}}$, and increased in the UUO $\mathbf{O}_{\mathrm{CK}}$. Addition of ouabain to the bath resulted in a smaller depolarization of $\mathrm{V}_{\mathrm{B}}$ in the $U \mathrm{UO}_{\mathrm{OK}}$, but in a greater depolarization in the $\mathrm{UUO}_{\mathrm{CK}}$. Upon lowering bath $\mathrm{Cl}^{-}$, the change in basolateral membrane electromotive force ( $\triangle \mathrm{EMF}$ ) was increased in the $U U O_{O K}$, and decreased in the $U U O_{C K}$. Reversely, upon raising bath $\mathrm{K}^{+}$, the $\triangle \mathrm{EMF}$ was decreased in the UUO ${ }_{\mathrm{OK}}$, and increased in the $\mathrm{UUO}_{\mathrm{CK}}$. We conclude: $(a)$ the conductances of $\mathrm{Na}^{+}$and $\mathrm{K}^{+}$in the apical membrane, and active $\mathrm{Na}^{+}-\mathrm{K}^{+}$pump activity and relative $\mathrm{K}^{+}$conductance in the basolateral membrane are decreased in the $\mathrm{UUO}_{\mathrm{oK}}$, and increased in the $\mathrm{UUO}_{\mathrm{CK}} ;(b)$ the relative basolateral membrane $\mathrm{Cl}^{-}$conductance was increased in the $\mathrm{UUO}_{\mathrm{OK}}$, and decreased in the UUO $_{\mathrm{CK}}$ - (J. Clin. Invest. 1993. 92:571-581.) Key words: electrophysiology • potassium conductance • sodium conductance • sodium pump • unilateral ureteral obstruction
\end{abstract}

Part of this work has been published in abstract form (1992. J. Am. Soc. Nephrol. 3:815).

Address reprint requests to Dr. Shigeaki Muto, Department of Nephrology, Jichi Medical School, Minamikawachi, Tochigi 329-04, Japan.

Received for publication 16 November 1992 and in revised form 12 March 1993.

J. Clin. Invest.

(c) The American Society for Clinical Investigation, Inc.

$0021-9738 / 93 / 08 / 0571 / 11 \quad \$ 2.00$

Volume 92, August 1993, 571-581

\section{Introduction}

Unilateral ureteral obstruction (UUO) ${ }^{1}$ causes a number of alterations in renal function of both obstructed and untouched contralateral kidneys $(1,2)$. Abnormalities in $\mathrm{Na}^{+}$and water conservation and in $\mathrm{H}^{+}$and $\mathrm{K}^{+}$excretion (3-9) are known to occur in the distal nephron segments, including the cortical collecting duct (CCD), from the obstructed kidney after UUO. However, the mechanisms underlying these disorders have not been fully evaluated. Only a few studies have assessed some of them at a segmental level. The in vitro microperfusion studies of the rabbit CCD have demonstrated that ureteral obstruction led to decreases in the lumen-negative transepithelial voltage $(6,8)$ as well as in $\mathrm{Na}^{+}$reabsorption (6). These changes also included decreases in $\mathrm{Na}^{+}-\mathrm{K}^{+}$-ATPase activity (9) and in $\mathrm{Na}^{+}-\mathrm{K}^{+}$pump in situ turnover (4) in the CCD from the obstructed rat kidney after UUO. These observations have suggested that the collecting duct (CD) cell would be functionally impaired after ureteral obstruction, because the $C D$ cell is mainly responsible for $\mathrm{Na}^{+}$and $\mathrm{K}^{+}$transports in the CCD (10-15). However, the cellular mechanisms of the defects in $\mathrm{Na}^{+}$and $\mathrm{K}^{+}$transports in the CCD from obstructed kidneys remain unknown.

In addition, there is little information regarding the distal nephron function of contralateral kidneys after UUO. Most studies have been performed to characterize the distal nephron function of the obstructed kidney as compared to that of the contralateral kidney. Both unilateral nephrectomy (UNX) $(16,17)$ and UUO $(18-20)$ result in adaptive increases in the size and the function of the contralateral kidney. Among the remaining nephrons, the CCDs from the remnant kidney after UNX also exhibit adaptive increase in $\mathrm{Na}^{+}$reabsorption (21) and $\mathrm{K}^{+}$secretion (22). These adaptive changes are accompanied by an increase in $\mathrm{Na}^{+}-\mathrm{K}^{+}$-ATPase activity (23) and an amplification of the basolateral membrane of the CD cell (24). Very recently, we have demonstrated that the CCDs from the remnant kidney in rabbits $14 \mathrm{~d}$ after UNX had structural hypertrophy, and that conductances of $\mathrm{Na}^{+}$and $\mathrm{K}^{+}$in the apical

1. Abbreviations used in this paper: $\mathrm{CCD}$, cortical collecting duct; $\mathrm{CD}$ cell, collecting duct cell; control, sham operation; DOCA, deoxycorticosterone acetate; $\triangle \mathrm{EMF}$, change in basolateral membrane electromotive force due to ion substitution; $f R_{A}$, fractional apical membrane resistance, $G_{A}$, apical membrane conductance; $G_{B}$, basolateral membrane conductance; $\mathrm{G}_{\mathrm{T}}$, transepithelial conductance; $\mathrm{G}_{\mathrm{T} j}$, tight junction conductance; UUO, unilateral ureteral obstruction; $\mathrm{UUO}_{\mathrm{CK}}$, contralateral kidney from unilateral ureteral obstruction; $\mathrm{UUO}_{\mathrm{OK}}$, obstructed kidney from unilateral ureteral obstruction; UNX, unilateral nephrectomy; $\mathrm{V}_{\mathrm{A}}$, apical membrane voltage; $\mathrm{V}_{\mathrm{B}}$, basolateral membrane voltage; $V_{T}$, transepithelial voltage. 
membrane as well as active $\mathrm{Na}^{+}-\mathrm{K}^{+}$-ATPase pump activity and $\mathrm{K}^{+}$conductance in the basolateral membrane of the $\mathrm{CD}$ cell from the contralateral kidney are stimulated (25). Thus, the chronic adaptations in tubular size, and $\mathrm{Na}^{+}$and $\mathrm{K}^{+}$transport properties in the CCD have been well studied. However, less attention has been paid to the early alterations in tubular function and morphology that follow loss of functional renal mass.

Accordingly, the purpose of the present study was to determine the electrical properties of the apical as well as the basolateral membranes of the CD cell from the obstructed and contralateral kidneys $24 \mathrm{~h}$ after UUO.

In this article, we demonstrate that conductances of $\mathrm{Na}^{+}$and $\mathrm{K}^{+}$in the apical membrane, and electrogenic $\mathrm{Na}^{+}$$\mathrm{K}^{+}$-ATPase pump activity and relative $\mathrm{K}^{+}$conductance in the basolateral membrane of the $\mathrm{CD}$ cell are inhibited in the obstructed kidney, whereas they are stimulated in the contralateral kidney. We also found that the relative $\mathrm{Cl}^{-}$conductance of the basolateral membrane of the $\mathrm{CD}$ cell is increased in the obstructed kidney, while it is decreased in the contralateral kidney.

\section{Methods}

Animals and surgical procedures. Female Japanese white rabbits weighing $1.5-2.5 \mathrm{~kg}$ were used. Experiments were performed to use three groups of kidneys: sham-operated (in this study termed control), obstructed $\left(\mathrm{UUO}_{\mathrm{OK}}\right)$, and contralateral $\left(\mathrm{UUO}_{\mathrm{CK}}\right)$ kidneys $24 \mathrm{~h}$ after UUO. Left ureteral obstruction was performed, with sterile technique under light anesthesia with intravenous pentobarbital of $30 \mathrm{mg} / \mathrm{kg}$, by trying a 3-0 silk suture around the left ureter above the ureterovesicular junction. In control animals, the left ureter was manipulated but otherwise left intact. The control and UUO animals were then permitted to recover from anesthesia and were returned to their cages, with free access to food and water. The rabbits were maintained on standard rabbit laboratory diet (rabbit diet, Clea Japan, Inc., Tokyo) containing $\mathrm{Na}^{+}$of $120 \mathrm{meq} / \mathrm{kg}$ diet and $\mathrm{K}^{+}$of $400 \mathrm{meq} / \mathrm{kg}$ diet, and tap water ad lib.

Isolation and perfusion of tubules. $24 \mathrm{~h}$ after the surgery, blood was taken from control and UUO rabbits to determine plasma concentrations of $\mathrm{Na}^{+}, \mathrm{K}^{+}$, and $\mathrm{Cl}^{-}$. The control and $\mathrm{UUO}$ animals were then reanesthetized with intravenous sodium pentobarbital of $35 \mathrm{mg} / \mathrm{kg}$, and the both kidneys were removed and weighed. Slices of the coronal section 1-2 mm thick were made and transferred to a dish containing a cold intracellular fluid-like solution of the following composition $(\mathrm{mM}): 14 \mathrm{KCl}, 44 \mathrm{~K}_{2} \mathrm{HPO}_{4}, 14 \mathrm{KH}_{2} \mathrm{PO}_{4}, 9 \mathrm{NaHCO}_{3}$, and 160 sucrose. As described previously $(14,15,25)$, this dissection medium was selected because it has been reported that intracellular fluid-like solutions are much better in preserving kidney tissue metabolically as well as functionally. Segments of CCDs were dissected from the cortex, and transferred to a bath mounted on an inverted microscope (Diaphot; Nikon, Tokyo). Each tubule was perfused in vitro according to the techniques developed by Burg et al. (26) and as modified in this laboratory for the use of intracellular microelectrodes $(14,15,25)$. Because the details of the technique have been published previously $(14,15$, 25 ), they will be presented here only briefly. Tubules were suspended between the two pipettes. The luminal perfusion rate exceeded $20 \mathrm{nl} /$ min in all tubules. The distal end of the tubule was held in the collecting pipette with unpolymerized Sylgard 184 (Dow Corning Corp., Midland, MI). The tubule was perfused in the bathing chamber of $\sim 100 \mu$ l to permit rapid exchange of the bathing solution within $5 \mathrm{~s}$. The bathing solution flowed at $5-15 \mathrm{ml} / \mathrm{min}$ from the reservoirs by gravity through a water jacket to permit the bath temperature to be regulated at $37^{\circ} \mathrm{C}$.
Electrical measurements. The transepithelial and cellular electrical properties of the tubule were measured using techniques described previously in this laboratory $(14,15,25)$. In brief, the transepithelial voltage $\left(V_{T}\right)$ was measured through the perfusion pipette, which was connected to one channel of a dual-channel electrometer (Duo 773; W-P Instruments, Inc., New Haven, CT) with a $3 \mathrm{M} \mathrm{KCl}-3 \%$ agar bridge and a calomel half-cell electrode. The basolateral membrane voltage $\left(V_{B}\right)$ was measured with $0.5 \mathrm{M} \mathrm{KCl}$-filled microelectrodes, which were fabricated from borosilicate glass capillaries (GD-1.5; $1.5 \mathrm{~mm} \mathrm{OD,} 1.0 \mathrm{~mm}$ ID; Narishige Scientific Laboratory, Tokyo) by using a vertical puller (PE-2; Narishige Scientific Laboratory). Both voltages were referenced to the bath and were recorded on a four-pen chart recorder (R64; Rikadenki, Tokyo). Cable analysis was used to calculate the transepithelial conductance $\left(G_{\mathrm{T}}\right)$, and the fractional apical membrane resistance $\left(f R_{A}\right)$ as described in detail previously $(14,15,25)$. Constant-current pulses, $50 \mathrm{nA}$ ( $300 \mathrm{~ms}$ in duration, 10 -s interval), were injected into the tubule lumen via the perfusion pipette. The $f R_{A}$ was estimated from the ratio of the voltage deflection across the apical membrane and the voltage deflection across the entire epithelium at the point of impalement.

The conductances of the apical and basolateral membranes $\left(G_{A}\right.$ and $G_{B}$, respectively) and the tight junction conductance $\left(G_{T j}\right)$ were estimated using $2 \mathrm{mM} \mathrm{Ba}^{2+}$ in the lumen as a probe to the equation described previously $(11-13,25): G_{T}=\left(1-f R_{A}\right) G_{B}+G_{T j}$.

Ion substitution studies were conducted to determine the relative ion permselectivity of the basolateral membrane. When the ion concentration of the bathing solutions was changed, the initial peak change in $V_{B}$ was used with fast bath exchange rates (2-5 s) to minimize secondary effects such as changes in cellular ion activities. Voltage changes due to lowering bath $\mathrm{Cl}^{-}$and raising bath $\mathrm{K}^{+}$concentrations were corrected for liquid junction potentials with free-flowing $3 \mathrm{M} \mathrm{KCl} \mathrm{elec-}$ trodes. The change in basolateral membrane electromotive force due to ion substitution ( $\triangle \mathrm{EMF}$ ) was estimated according to the following equation (25): $\Delta E M F=\Delta V_{B}-I \cdot R_{B}$, where $\Delta V_{B}$ is the measured change in the $V_{B}$ due to ion substitution and $I \cdot R_{B}$ is the change in membrane potential due to the dissipation of energy from current flowing across the basolateral membrane resistance $\left(R_{B}\right)$. As described previously (25), the circular loop current (I) was estimated from $G_{T j}$ and the change in $V_{T}$ on ion substitution $\left(\Delta V_{T}\right)$ as $I=G_{T j} \cdot \Delta V_{T}$.

Identification of $C D$ cells. Electrical identification of $C D$ cells was performed according to the criteria described previously by Muto et al. (12-15). CD cells have a relatively lower $f R_{A}$, higher $V_{B}$, apical $\mathrm{Na}^{+}$ and $\mathrm{K}^{+}$conductances, and basolateral $\mathrm{K}^{+}$and $\mathrm{Cl}^{-}$conductances.

Solutions and materials. The composition of the control bathing and perfusing solution contained (in $\mathrm{mM}$ ): $110 \mathrm{NaCl}, 5 \mathrm{KCl}, 1 \mathrm{MgCl}_{2}$, $1.8 \mathrm{CaCl}_{2}, 25 \mathrm{NaHCO}_{3}, 10 \mathrm{Na}$ acetate, $0.8 \mathrm{Na}_{2} \mathrm{HPO}_{4}, 0.2 \mathrm{NaH}_{2} \mathrm{PO}_{4}, 5$ $\mathrm{L}$-alanine, and $8.3 \mathrm{D}$-glucose. This control solution had an osmolality between 285 and $295 \mathrm{mosmol} / \mathrm{kg} / \mathrm{H}_{2} \mathrm{O}$, and was equilibrated with $95 \% \mathrm{O}_{2} / 5 \% \mathrm{CO}_{2}$ and adjusted to $\mathrm{pH} 7.4$ at $37^{\circ} \mathrm{C}$. In some experiments, $45 \mathrm{mM} \mathrm{Na}^{+}$was replaced with $\mathrm{K}^{+}$, or $108.6 \mathrm{mM} \mathrm{Cl}^{-}$was replaced with cyclamate.

Amiloride (Sigma Chemical Co., St. Louis, MO) was added to the luminal perfusate to achieve a final concentration of $50 \mu \mathrm{M}$. Ouabain (Sigma Chemical Co.) was used in the bath at a concentration of $10^{-4}$ $\mathrm{M}$. $\mathrm{BaCl}_{2}$ was used at a final concentration of $2 \mathrm{mM}$.

Tubular measurements. Tubular lengths were measured at the end of each experiment with a calibrated reticle in the eyepiece of the microscope. The tubules were photographed during perfusion at a proximal, central, and distal site at a magnification of 200 . Inner and outer diameters were measured at $0.05-\mathrm{mm}$ intervals along the tubule. Reported values are the average of at least five measurements. Because the tubules from the three groups were rapidly perfused at similar rates and pressures, the degree of distention of the lumen is assumed to be similar in all.

Statistics. The data are expressed as mean \pm SE. Differences between groups were determined by the Student's $t$ test for either paired or nonpaired data as appropriate. $P$ values $<0.05$ were considered statistically significant. 


\section{Results}

\section{Effects of UUO on body and kidney weights}

Body weights in control and UUO animals were $1.75 \pm 0.07$ ( $n$ $=20)$ and $1.77 \pm 0.06(n=26) \mathrm{kg}$, respectively. There were no significant differences of body weights between the two groups of animals. Untouched right and left kidney weights in both groups of animals are given in Table I. In control animals, there were no significant differences of weights of right and left kidneys. By contrast, in UUO animals, the weights of the obstructed left kidney were significantly increased as compared to the untouched right kidney. Paulson and Fraley (27) also observed the same findings, in which the obstructed kidney weight in 40-d-old mice was significantly increased $24 \mathrm{~h}$ after UUO. In addition, the weights of the contralateral right kidney from UUO animals were not significantly different from those of sham-operated right kidneys.

\section{Comparison of plasma $\mathrm{Na}^{+}, \mathrm{K}^{+}$, and $\mathrm{Cl}^{-}$concentrations} in the two groups

Plasma $\mathrm{Na}^{+}, \mathrm{K}^{+}$, and $\mathrm{Cl}^{-}$concentrations from $18 \mathrm{UUO}$ animals were $143.7 \pm 0.9,4.2 \pm 0.1$, and $102.7 \pm 0.7 \mathrm{meq} /$ liter, respectively. These values were not significantly different from those from 16 control animals $\left(\mathrm{Na}^{+}, 141.4 \pm 1.1 \mathrm{meq} /\right.$ liter; $\mathrm{K}^{+}, 4.1 \pm 0.1 \mathrm{meq} /$ liter; $\mathrm{Cl}^{-}, 100.7 \pm 0.8 \mathrm{meq} /$ liter $)$.

\section{Electrophysiological data}

The length of the perfused tubule in the control, $\mathrm{UUO}_{\mathrm{OK}}$, and $\mathrm{UUO}_{\mathrm{CK}}$ groups was 960.9 $\pm 46.6(n=16), 870.0 \pm 66.7(n$ $=15)$, and $940.9 \pm 51.8(n=22) \mu \mathrm{m}$, respectively. Both inner and outer diameters of 15 tubules from the obstructed kidney were significantly greater than those of 16 tubules from the control kidney (inner diameter $37.6 \pm 1.2$ vs. $30.3 \pm 0.9 \mu \mathrm{m}, P$ $<0.001$; outer diameter $45.5 \pm 1.2$ vs. $40.4 \pm 1.1 \mu \mathrm{m}, P<0.01$ ). These findings are consistent with the notion that the change in inner diameter is more prominent than that in outer diameter after UUO. Luminal dilatation of the CCD segment from obstructed rat kidneys has also been reported to occur as early as $24 \mathrm{~h}$ after ureteral obstruction (28). On the other hand, the inner and outer diameters $(29.1 \pm 0.9$ and $39.1 \pm 0.8 \mu \mathrm{m}$, respectively) of 22 tubules from the contralateral kidney after UUO were not significantly different from those in the control kidney.

Effects of UUO on barrier voltages and conductances of the $C D$ cell from obstructed and contralateral kidneys. The effects of UUO on barrier voltages of the CD cells of tubules from obstructed and contralateral kidneys are illustrated in Fig. 1. We found that not only $-\mathrm{V}_{\mathrm{T}}$ (control $-8.6 \pm 1.1 \mathrm{mV}, n=17$;

Table I. Effects of UUO on Kidney Weights

\begin{tabular}{|c|c|c|c|}
\hline & $\begin{array}{l}\text { Left kidney } \\
\text { weight }\end{array}$ & $\begin{array}{l}\text { Right kidney } \\
\text { weight }\end{array}$ & $P$ \\
\hline \multicolumn{4}{|c|}{$g$} \\
\hline Control $(n=19)$ & $6.6 \pm 0.3$ & $6.4 \pm 0.3$ & NS \\
\hline UUO $(n=25)$ & $12.3 \pm 0.5$ & $6.6 \pm 0.2$ & $<0.001$ \\
\hline$P$ & $<0.001$ & NS & \\
\hline
\end{tabular}

Values are mean \pm SE. $n$, number of kidneys.

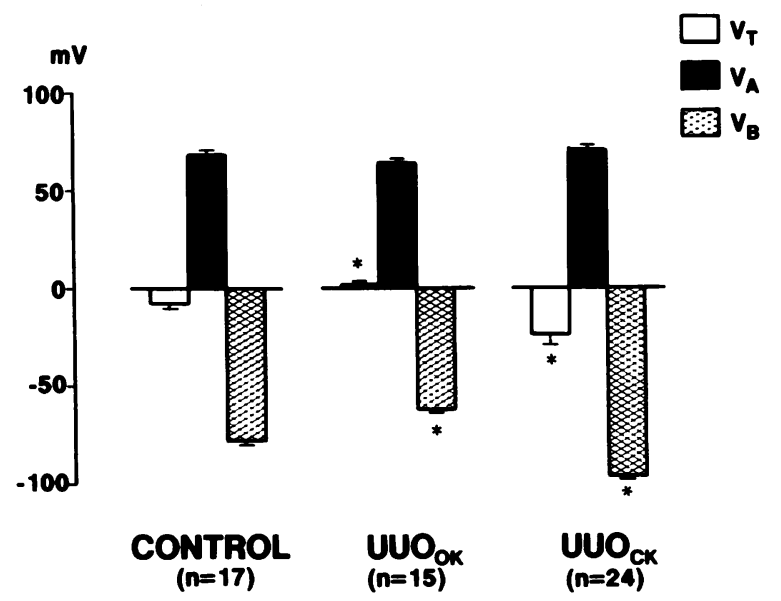

Figure 1. Effects of unilateral ureteral obstruction on barrier voltages of the $C D$ cell from obstructed and contralateral kidneys. Values are mean \pm SE. ${ }^{*} P<0.001$ compared to control.

$\mathrm{UUO}_{\mathrm{OK}} 2.3 \pm 1.2 \mathrm{mV}, n=15$ ) was much lower in the tubules from the obstructed kidney but also $-\mathrm{V}_{\mathrm{B}}$ (control $-77.8 \pm 1.9$ $\mathrm{mV}, n=17 ; \mathrm{UUO}_{\mathrm{OK}}-62.0 \pm 1.8 \mathrm{mV}, n=15$ ) was also reduced by $\sim 15 \mathrm{mV}$. In contrast to the tubules from the obstructed kidney, $-\mathrm{V}_{\mathrm{T}}(-23.9 \pm 2.5 \mathrm{mV}, n=24)$ and $-\mathrm{V}_{\mathrm{B}}(-95.8 \pm 1.9$ $\mathrm{mV}, n=24$ ) of the tubules from the contralateral kidney after UUO were significantly greater than those from the control kidney. These measurements of cell potentials are consistent with the notion that active electrogenic $\mathrm{Na}^{+}$transport across the basolateral membrane is inhibited in the $\mathrm{UUO}_{\mathrm{OK}}$, and stimulated in the $\mathrm{UUO}_{\mathrm{CK}}$. The calculated apical membrane voltage $\left(\mathrm{V}_{\mathrm{A}}\right)$ in the $\mathrm{UUO}_{\mathrm{OK}}(64.4 \pm 2.0 \mathrm{mV}, n=15)$ and $\mathrm{UUO}_{\mathrm{CK}}$ (72.7 $\pm 1.5 \mathrm{mV}, n=24$ ) was not significantly different from that in the control $(69.3 \pm 2.0 \mathrm{mV}, n=17)$.

Table II shows the effects of UUO on $f R_{A}$ and barrier conductances of the $C D$ cell from obstructed and contralateral kidneys. The $f R_{A}$ was significantly elevated and the $G_{T}$ was significantly reduced in the $\mathrm{UUO}_{\mathrm{OK}}$ group, indicating that UUO affects the conductive pathway of the apical membrane of the obstructed tubule more than that of the basolateral membrane. This notion was also supported by the fact that the $\mathrm{G}_{A}$ was significantly lower in the $\mathrm{UUO}_{\mathrm{OK}}$ group. However, either $G_{B}$ or $G_{T j}$ in the $C D$ cell from the obstructed kidney was not significantly changed. By contrast, the $G_{T}$ was significantly increased in parallel with increases in $G_{A}$ and $G_{B}$ in the $U U O_{C K}$ group, although neither the $\mathrm{fR}_{\mathrm{A}}$ nor the $\mathrm{G}_{\mathrm{T} j}$ was changed.

Effects of UUO on electrical properties of the apical membrane of the CD cell from obstructed and contralateral kidneys. As described above, UUO induced a decrease in $G_{A}$ in the $\mathrm{UUO}_{\mathrm{OK}}$, but an increase in $\mathrm{G}_{\mathrm{A}}$ in the $\mathrm{UUO}_{\mathrm{CK}}$. The first set of the studies was, therefore, designed to examine whether this alteration in $G_{A}$ is the result of a change in the $\mathrm{Na}^{+}$conductance and/or $\mathrm{K}^{+}$conductance in the apical membrane of the CD cell.

To examine whether the $\mathrm{Na}^{+}$conductance in the apical membrane of the $C D$ cell from obstructed and contralateral kidneys is affected upon UUO, we added a $\mathrm{Na}^{+}$channel inhibitor, amiloride, to the luminal perfusate and compared the barrier voltages and conductances, as shown in Table III. Upon addition of $50 \mu \mathrm{M}$ amiloride to the perfusate, the $V_{T}$ and $V_{B}$ in the tubules of the three different groups were rapidly depolar- 
Table II. Effects of UUO on $f R_{A}$ and Barrier Conductances in the CCD from Obstructed and Contralateral Kidneys

\begin{tabular}{|c|c|c|c|c|c|}
\hline & $\mathrm{fR}_{\mathrm{A}}$ & $\mathrm{G}_{\mathrm{T}}$ & $\mathrm{G}_{\mathrm{A}}$ & $\mathrm{G}_{\mathrm{B}}$ & $\mathrm{G}_{\mathrm{Tj}}$ \\
\hline & & \multicolumn{4}{|c|}{$\mathrm{mS} \cdot \mathrm{cm}^{-2}$} \\
\hline Control $(n=15)$ & $0.40 \pm 0.03$ & $8.6 \pm 0.4$ & $14.8 \pm 2.0$ & $9.4 \pm 1.1$ & $3.3 \pm 0.3$ \\
\hline $\mathrm{UUO}_{\mathrm{OK}}(n=11)$ & $0.59 \pm 0.04^{\ddagger}$ & $5.9 \pm 0.7^{\ddagger}$ & $4.8 \pm 0.5^{\S}$ & $7.6 \pm 1.3$ & $3.2 \pm 0.7$ \\
\hline $\mathrm{UUO}_{\mathrm{CK}}(n=12)$ & $0.33 \pm 0.04$ & $11.5 \pm 0.8^{\ddagger}$ & $36.5 \pm 6.0^{\ddagger}$ & $14.6 \pm 1.6^{*}$ & $2.4 \pm 0.4$ \\
\hline
\end{tabular}

Values are mean \pm SE. $n$, number of tubules. ${ }^{*} P<0.05,{ }^{\ddagger} P<0.005,{ }^{\S} P<0.001$ vs. control.

ized, resulting in a significant hyperpolarization of $V_{A}$. At that time, the $G_{T}$ was significantly decreased and the $f R_{A}$ was significantly increased in the three groups. However, the amiloridesensitive changes in $V_{A}, G_{T}$, and $f R_{A}$ were significantly reduced in the $\mathrm{UUO}_{\mathrm{OK}}$ group, and significantly elevated in the $\mathrm{UUO}_{\mathrm{CK}}$ group (Fig. 2). Therefore, these results indicate that the amiloride-sensitive $\mathrm{Na}^{+}$conductance in the apical membrane of the CD cell is reduced in the $\mathrm{UUO}_{\mathrm{OK}}$ group, while it is elevated in the $\mathrm{UUO}_{\mathrm{CK}}$ group.

The next set of studies was designed to examine whether or not the apical membrane $\mathrm{K}^{+}$conductance of the $\mathrm{CD}$ cell in the tubules from obstructed and contralateral kidneys is changed. Therefore, we determined the effects of raising the luminal perfusate $\mathrm{K}^{+}$concentration from 5 to $50 \mathrm{mM}$ on barrier voltage and conductances at the initial peak response in the three groups (Table IV). When the perfusate $\mathrm{K}^{+}$concentration was increased in the tubules of the three groups, the $V_{T}$ was rapidly hyperpolarized and the $V_{B}$ was rapidly depolarized, resulting in a significant depolarization of $V_{A}$. At that time, the $G_{T}$ was significantly increased, and the $f R_{A}$ was significantly decreased in the three groups. Although similar pattern of the responses of $V_{A}, G_{T}$, and $f R_{A}$ was observed in the tubules of the three groups, the changes in $V_{A}$ and $G_{T}$ were significantly lower in the $\mathrm{UUO}_{\mathrm{OK}}$ group, and significantly greater in the $\mathrm{UUO}_{\mathrm{CK}}$ group (Fig. 3). These results indicate that the apical membrane $\mathrm{K}^{+}$conductance is decreased in the $\mathrm{UUO}_{\mathrm{OK}}$ group, but increased in the $\mathrm{UUO}_{\mathrm{CK}}$ group.

To further characterize the $\mathrm{K}^{+}$conductive property in the apical membrane of the $\mathrm{CD}$ cell from obstructed and contralateral kidneys, we added a $\mathrm{K}^{+}$channel inhibitor, $\mathrm{Ba}^{2+}$, to the luminal perfusate and observed the electrical properties at the initial peak response (Table V). When $2 \mathrm{mM} \mathrm{Ba}^{2+}$ was added to the perfusate in the tubules of the three groups, the $V_{T}$ was rapidly hyperpolarized, and the $V_{B}$ was rapidly depolarized, resulting in a significant depolarization of $V_{A}$. At that time, the $G_{T}$ was significantly decreased, and the $f R_{A}$ was significantly increased in the tubules of the three groups. However, the $\mathrm{Ba}^{2+}$-sensitive changes in $V_{A}, G_{T}$, and $f R_{A}$ were significantly lower in the $\mathrm{UUO}_{\mathrm{OK}}$ group (Fig. 4). In contrast, the $\mathrm{Ba}^{2+}$-sensitive changes in $V_{A}$ and $G_{T}$ were significantly greater in the $\mathrm{UUO}_{\mathrm{CK}}$ group (Fig. 4). From these results it is concluded that the $\mathrm{Ba}^{2+}$-sensitive $\mathrm{K}^{+}$conductance in the apical membrane is decreased in the $\mathrm{UUO}_{\mathrm{OK}}$ group, and increased in the $\mathrm{UUO}_{\mathrm{CK}}$ group.

Effects of UUO on electrical properties of the basolateral membrane of the CD cell from obstructed and contralateral kidneys. As shown in Fig. 1, the $-\mathrm{V}_{\mathrm{B}}$ was reduced by $\sim 15 \mathrm{mV}$ in the tubules from the obstructed kidney, and was increased by $\sim 20 \mathrm{mV}$ in the tubules from the contralateral kidney. These findings suggest that the $\mathrm{Na}^{+}-\mathrm{K}^{+}$-ATPase pump activity in the basolateral membrane of the $\mathrm{CD}$ cell is inhibited in the obstructed kidney, whereas it is stimulated in the contralateral kidney. To further confirm this notion, we added a $\mathrm{Na}^{+}-\mathrm{K}^{+}$ pump inhibitor, ouabain, to the bath, and observed the barrier voltages and conductances at the initial peak response. As shown in Table VI, in the three groups of the tubules addition of $10^{-4} \mathrm{M}$ ouabain to the bath caused both $\mathrm{V}_{\mathrm{T}}$ and $\mathrm{V}_{\mathrm{B}}$ to depolarize significantly without any changes in $G_{T}$ or $f R_{A}$. However, the initial peak change was significantly reduced in the $\mathrm{UUO}_{\mathrm{OK}}$ group, but significantly increased in the $\mathrm{UUO}_{\mathrm{CK}}$ group

Table III. Effects of $50 \mu M$ Amiloride in the Lumen on Barrier Voltages and Conductances at the Initial Peak Response

\begin{tabular}{|c|c|c|c|c|c|}
\hline & $\mathbf{v}_{\mathbf{T}}$ & $\mathrm{V}_{\mathbf{B}}$ & $\mathrm{V}_{\mathrm{A}}$ & $\mathrm{G}_{\mathrm{T}}$ & $\mathbf{f R}_{\mathbf{A}}$ \\
\hline & & $m V$ & & $\mathrm{mS} \cdot \mathrm{cm}^{-2}$ & \\
\hline \multicolumn{6}{|l|}{ Control } \\
\hline Without amiloride & $-8.2 \pm 0.8(14)$ & $-80.2 \pm 2.3(14)$ & $71.9 \pm 2.3(14)$ & $8.1 \pm 0.7(11)$ & $0.43 \pm 0.06(11)$ \\
\hline With amiloride & $1.9 \pm 0.3^{\S}(14)$ & $-75.6 \pm 2.6^{\S}(14)$ & $77.6 \pm 2.6^{8}(14)$ & $6.5 \pm 0.6^{8}(11)$ & $0.58 \pm 0.05^{\S}(11)$ \\
\hline \multicolumn{6}{|l|}{$\mathrm{UUO}_{\mathrm{OK}}$} \\
\hline Without amiloride & $3.5 \pm 1.3(8)$ & $-62.8 \pm 2.5(8)$ & $66.3 \pm 2.4(8)$ & $5.7 \pm 0.5(7)$ & $0.53 \pm 0.07(7)$ \\
\hline With amiloride & $8.0 \pm 1.8^{\S}(8)$ & $-60.2 \pm 2.6^{8}(8)$ & $68.3 \pm 2.6^{\S}(8)$ & $4.4 \pm 0.4^{*}(7)$ & $0.60 \pm 0.08 *(7)$ \\
\hline \multicolumn{6}{|l|}{$\mathrm{UUO}_{\mathrm{CK}}$} \\
\hline Without amiloride & $-21.5 \pm 1.6(10)$ & $-94.6 \pm 2.2(10)$ & $73.4 \pm 2.1(10)$ & $10.1 \pm 0.6(6)$ & $0.37 \pm 0.04(6)$ \\
\hline With amiloride & $6.1 \pm 1.5^{\S}(10)$ & $-79.7 \pm 2.3^{\S}(10)$ & $85.8 \pm 2.6^{\S}(10)$ & $4.8 \pm 0.4^{\S}(6)$ & $0.70 \pm 0.04^{\ddagger}(6)$ \\
\hline
\end{tabular}

Values are mean \pm SE. Data were obtained from the same experiments. Numerals in parentheses indicate number of experiments. ${ }^{*} P<0.05$, ${ }^{\ddagger} P<0.01,{ }^{\S} P<0.001$ compared to the preceding period. 

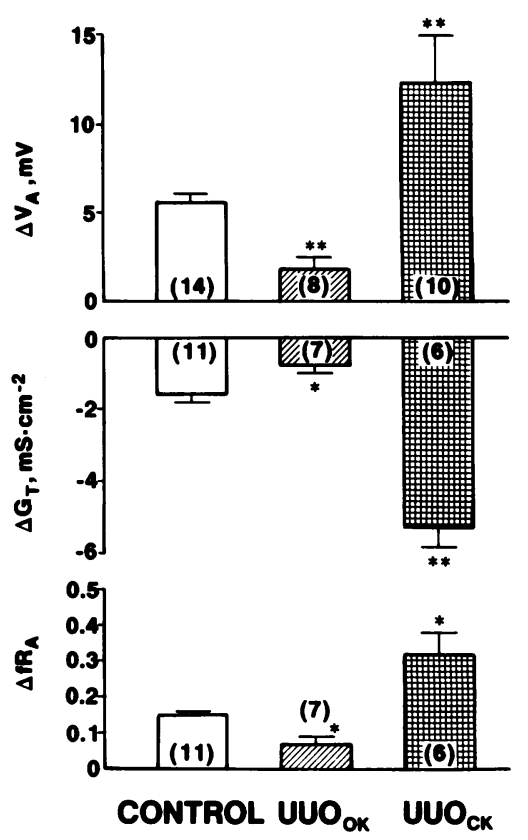

Figure 2. Comparison of the amiloride-sensitive changes in $V_{A}, G_{T}$, and $f R_{A}$ among the three groups. Values are mean \pm SE. Numerals in parentheses indicate number of experiments. ${ }^{*} P<0.05,{ }^{* *} P<0.001$ compared to control.
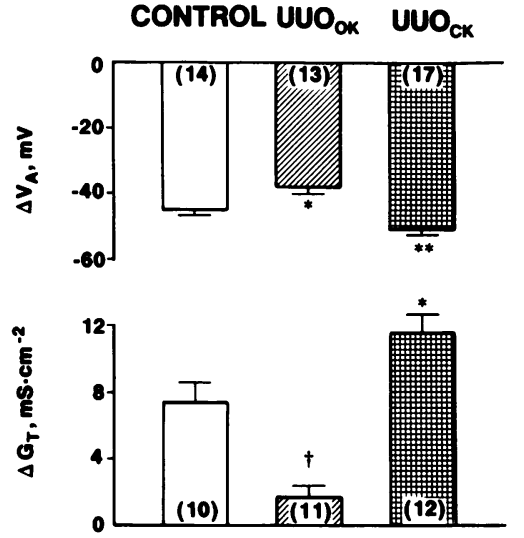

Figure 3. Comparison of the changes in $V_{A}$, $G_{T}$, and $f R_{A}$ upon raising the luminal perfusate $\mathrm{K}^{+}$concentration from 5 to $50 \mathrm{mM}$ among the three groups. Values are mean \pm SE.

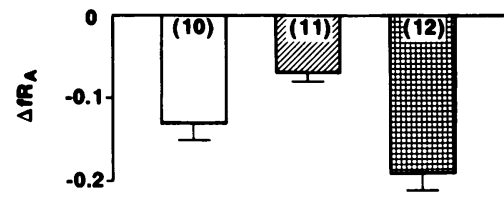

Numerals in parentheses indicate number of experiments. ${ }^{*} P<0.01$, ${ }^{* *} P<0.005,{ }^{\dagger} P$ $<0.001$ compared to control.
(Fig. 5). Taken together, the $\mathrm{Na}^{+}-\mathrm{K}^{+}$pump activity in the basolateral membrane of the $\mathrm{CD}$ cell is inhibited in the $\mathrm{UUO}_{\mathrm{OK}}$ group, while it is stimulated in the $\mathrm{UUO}_{\mathrm{CK}}$ group.

The conductive pathway of the basolateral membrane from the normal rabbit kidney is composed of a dominant $\mathrm{Cl}^{-}$conductive pathway and a small $\mathrm{K}^{+}$conductive pathway $(12,14)$. In the basolateral membrane, the coupled influx of $\mathrm{K}^{+}$via the $\mathrm{Na}^{+}-\mathrm{K}^{+}$-ATPase pump is "recycled" via this basolateral $\mathrm{K}^{+}$ conductance. Thus, the change in $\mathrm{Na}^{+}-\mathrm{K}^{+}$pump activity described above would influence the basolateral $\mathrm{K}^{+}$conductance. Therefore, we compared the relative ion conductive properties of the basolateral membrane of the three groups of tubules using rapid exchange rates of bath. When the bath $\mathrm{K}^{+}$concentration was increased from 5 to $50 \mathrm{mM}$, the basolateral membrane in the tubules of the three groups was rapidly depolarized. However, the initial peak change in $\mathrm{V}_{\mathrm{B}}$ was lower in the UUO $_{\mathrm{OK}}$ group $(9.0 \pm 0.9 \mathrm{mV}, n=19, P<0.05)$ and greater in the $\mathrm{UUO}_{\mathrm{CK}}$ group $(29.5 \pm 2.0 \mathrm{mV}, n=33, P<0.001)$ when compared with the control group $(12.6 \pm 1.3 \mathrm{mV}, n=14)$. Simultaneously, the $\triangle \mathrm{EMF}$ was lower in the $\mathrm{UUO}_{\mathrm{OK}}$ group
( $7.0 \pm 0.8$ vs. $9.9 \pm 0.9 \mathrm{mV}, P<0.05)$ and greater in the $\mathrm{UUO}_{\mathrm{CK}}$ group ( $25.8 \pm 1.9 \mathrm{mV}, P<0.001$ ) (Fig. 6). When the bath $\mathrm{Cl}^{-}$ concentration was decreased from 120.6 to $12 \mathrm{mM}$, the basolateral membrane in the tubules of the three groups was rapidly depolarized. However, the initial peak change in $\mathrm{V}_{\mathrm{B}}$ was significantly greater in the $\mathrm{UUO}_{\mathrm{OK}}$ group $(31.2 \pm 2.0 \mathrm{mV}, n=12, P$ $<0.01)$ than in the control group $(23.8 \pm 1.3 \mathrm{mV}, n=11)$. In contrast to the $\mathrm{UUO}_{\mathrm{OK}}$ group, the magnitude of the initial peak depolarization of $\mathrm{V}_{\mathrm{B}}$ was significantly lower in the $\mathrm{UUO}_{\mathrm{CK}}$ group $(16.0 \pm 1.0 \mathrm{mV}, n=14, P<0.001)$. Simultaneously, the $\triangle \mathrm{EMF}$ was greater in the $\mathrm{UUO}_{\mathrm{OK}}$ group $(36.0 \pm 0.8$ vs. $27.0 \pm 1.4 \mathrm{mV}, P<0.001)$, and lower in the $\mathrm{UUO}_{\mathrm{CK}}$ group (16.0 $\pm 1.0 \mathrm{mV}, n=14, P<0.001$ ) (Fig. 6).

Table VII shows the effects of raising the bath $\mathrm{K}^{+}$concentration on barrier voltages and conductances at the initial peak response. Upon raising the bath $\mathrm{K}^{+}$concentration in the tubules of the three groups, the $G_{T}$ and the $f R_{A}$ were significantly increased. As shown in Fig. 7, however, the changes in $G_{T}$ and $f R_{A}$ were significantly decreased in the $U_{U O}$ group, and significantly increased in the $\mathrm{UUO}_{\mathrm{CK}}$ group. From these obser-

Table IV. Effect of Luminal $\mathrm{K}^{+}$Elevation from 5 to $50 \mathrm{mM}$ on Barrier Voltages and Conductances at the Initial Peak Response

\begin{tabular}{|c|c|c|c|c|c|}
\hline & $\mathrm{V}_{\mathrm{T}}$ & $\mathrm{V}_{\mathbf{B}}$ & $\mathrm{v}_{\mathrm{A}}$ & $\mathrm{G}_{\mathrm{T}}$ & $\mathrm{fR}_{\mathrm{A}}$ \\
\hline & & $m V$ & & $\mathrm{mS} \cdot \mathrm{cm}^{-2}$ & \\
\hline \multicolumn{6}{|l|}{ Control } \\
\hline $\mathrm{K}^{+} 5 \mathrm{mM}$ & $-8.4 \pm 1.9(14)$ & $-76.8 \pm 1.9(14)$ & $68.3 \pm 2.5(14)$ & $8.3 \pm 0.3(10)$ & $0.49 \pm 0.04(10)$ \\
\hline $\mathrm{K}^{+} 50 \mathrm{mM}$ & $-26.9 \pm 2.7^{\S}(14)$ & $-50.1 \pm 2.5^{\S}(14)$ & $23.2 \pm 1.7^{\S}(14)$ & $15.7 \pm 1.5^{\S}(10)$ & $0.36 \pm 0.04^{\S}(10)$ \\
\hline \multicolumn{6}{|l|}{ UUO $_{\text {OK }}$} \\
\hline $\mathrm{K}^{+} 5 \mathrm{mM}$ & $3.0 \pm 1.1(13)$ & $-64.2 \pm 1.9(13)$ & $67.2 \pm 2.3(13)$ & $4.7 \pm 0.7(11)$ & $0.59 \pm 0.05(11)$ \\
\hline $\mathrm{K}^{+} 50 \mathrm{mM}$ & $-5.9 \pm 2.3^{\ddagger}(13)$ & $-33.6 \pm 2.1^{\S}(13)$ & $27.7 \pm 1.8^{\S}(13)$ & $6.5 \pm 1.3 *(11)$ & $0.52 \pm 0.04^{\ddagger}(11)$ \\
\hline \multicolumn{6}{|l|}{$\mathrm{UUO}_{\mathrm{CK}}$} \\
\hline $\mathrm{K}^{+} 5 \mathrm{mM}$ & $-21.1 \pm 1.3(17)$ & $-96.5 \pm 2.3(17)$ & $75.5 \pm 2.8(17)$ & $10.4 \pm 0.7(12)$ & $0.31 \pm 0.03(12)$ \\
\hline $\mathrm{K}^{+} 50 \mathrm{mM}$ & $-44.4 \pm 2.0^{\S}(17)$ & $-69.5 \pm 2.8^{5}(17)$ & $25.4 \pm 2.4^{\S}(17)$ & $22.0 \pm 1.0^{\ddagger}(12)$ & $0.12 \pm 0.02^{\S}(12)$ \\
\hline
\end{tabular}

Values are mean \pm SE. Data were obtained from the same experiments. Numerals in parentheses indicate number of experiments. ${ }^{*} P<0.05$, ${ }^{\ddagger} P<0.005,{ }^{8} P<0.001$ compared to the preceding period. 
Table V. Effect of $2 \mathrm{mM} \mathrm{Ba}^{2+}$ in the Lumen on Barrier Voltages and Conductances at the Initial Peak Response

\begin{tabular}{|c|c|c|c|c|c|}
\hline & $\mathrm{V}_{\mathrm{T}}$ & $\mathrm{V}_{\mathbf{B}}$ & $\mathrm{v}_{\mathrm{A}}$ & $\mathrm{G}_{\mathrm{T}}$ & $\mathbf{f} \mathbf{R}_{\wedge}$ \\
\hline & & $m V$ & & $\mathrm{mS} \cdot \mathrm{cm}^{-2}$ & \\
\hline \multicolumn{6}{|l|}{ Control } \\
\hline Without $\mathbf{B a}^{2+}$ & $-8.2 \pm 1.1(19)$ & $-77.1 \pm 1.9(19)$ & $68.6 \pm 2.1(19)$ & $8.6 \pm 0.4(15)$ & $0.40 \pm 0.03(15)$ \\
\hline With $\mathrm{Ba}^{2+}$ & $-12.1 \pm 1.5^{*}(19)$ & $-51.1 \pm 2.4^{*}(19)$ & $38.8 \pm 2.5^{*}(19)$ & $4.5 \pm 0.3^{*}(15)$ & $0.84 \pm 0.01 *(15)$ \\
\hline \multicolumn{6}{|l|}{$\mathrm{UUO}_{\mathrm{OK}}$} \\
\hline Without $\mathrm{Ba}^{2+}$ & $3.4 \pm 1.1(11)$ & $-62.1 \pm 1.5(11)$ & $65.4 \pm 1.8(11)$ & $5.9 \pm 0.7(11)$ & $0.59 \pm 0.04(11)$ \\
\hline With $\mathrm{Ba}^{2+}$ & $0.6 \pm 1.0^{*}(11)$ & $-41.4 \pm 2.3^{*}(11)$ & $42.0 \pm 2.4^{*}(11)$ & $3.9 \pm 0.7^{*}(11)$ & $0.89 \pm 0.01 *(11)$ \\
\hline \multicolumn{6}{|l|}{$\mathrm{UUO}_{\mathrm{CK}}$} \\
\hline Without $\mathrm{Ba}^{2+}$ & $-21.9 \pm 1.5(15)$ & $-98.7 \pm 2.1(15)$ & $76.8 \pm 2.2(15)$ & $11.5 \pm 0.8(12)$ & $0.33 \pm 0.04(12)$ \\
\hline With $\mathrm{Ba}^{2+}$ & $-32.3 \pm 1.6^{*}(15)$ & $-72.9 \pm 3.2 *(15)$ & $40.6 \pm 3.5^{*}(15)$ & $4.6 \pm 0.5^{*}(12)$ & $0.80 \pm 0.02 *(12)$ \\
\hline
\end{tabular}

Values are mean \pm SE. Data were obtained from the same experiments. Numerals in parentheses include number of experiments. ${ }^{*} P<0.001$ compared to the preceding period.

vations, it is indicated that the relative $\mathrm{K}^{+}$conductance is decreased in the $\mathrm{UUO}_{\mathrm{OK}}$ group and increased in the $\mathrm{UUO}_{\mathrm{CK}}$ group, whereas the relative $\mathrm{Cl}^{-}$conductance is increased in the $\mathrm{UUO}_{\mathrm{OK}}$ group and decreased in the $\mathrm{UUO}_{\mathrm{CK}}$ group.

To further characterize the basolateral membrane $\mathrm{K}^{+}$conductive property in the $\mathrm{UUO}_{\mathrm{CK}}$ group, we added $2 \mathrm{mM} \mathrm{Ba}^{2+}$ to the bath, and observed the electrical parameters. Table VIII summarizes the effects of $\mathrm{Ba}^{2+}$ to the bath on electrical properties at the initial peak response. In the control group, addition of $\mathrm{Ba}^{2+}$ to the bath had no significant effects on $\mathrm{V}_{\mathrm{T}}$ and $\mathrm{V}_{\mathrm{B}}$, although it caused both $G_{T}$ and $f R_{A}$ to decrease significantly. These findings indicate that $\mathrm{K}^{+}$is close to equilibrium across the basolateral membrane. In sharp contrast to the control group, $2 \mathrm{mM} \mathrm{Ba}^{2+}$ was added to the $\mathrm{UUO}_{\mathrm{CK}}$ group, both $\mathrm{V}_{\mathrm{T}}$ and $V_{B}$ were rapidly hyperpolarized with decreases in $G_{T}$ and $f R_{A}$. These results are consistent with $\mathrm{Ba}^{2+}$ blockade of $\mathrm{K}^{+}$ current directed into the cell from the bath in the $\mathrm{UUO}_{\mathrm{CK}}$ group. These findings are also reported in the CCDs from deoxycorticosterone acetate (DOCA)-treated rabbits (29) and in the CCDs from the remnant kidney $14 \mathrm{~d}$ after UNX (25).

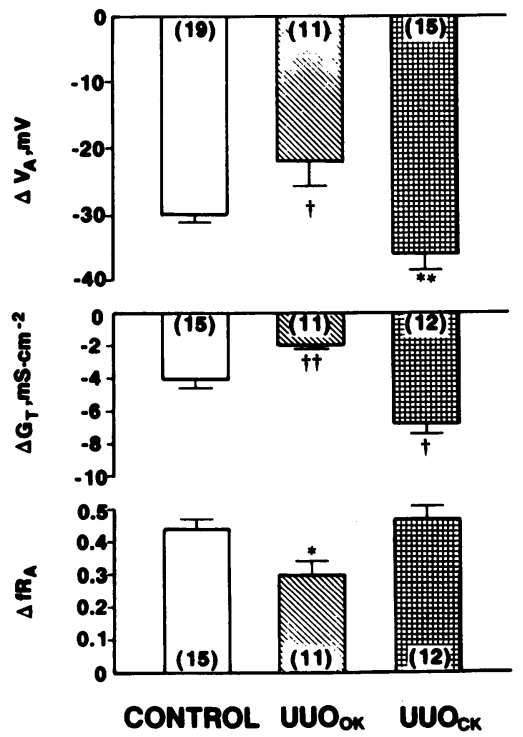

Figure 4. Comparison of the changes in $V_{A}$, $G_{T}$, and $f R_{A}$ upon addition of luminal $\mathrm{Ba}^{2+}$ among the three groups. Values are mean $\pm \mathrm{SE}$. Numerals in parentheses indicate number of experiments. ${ }^{*} P<0.05$, ${ }^{* *} P<0.01,{ }^{\dagger} P<0.005$, ${ }^{t \dagger} P<0.001$ compared to control.

\section{Discussion}

The present study was designed to determine the electrical properties of the apical as well as the basolateral membranes of the CD cell from obstructed and contralateral kidneys $24 \mathrm{~h}$ after UUO. The electrical properties observed in the CD cell from the obstructed kidney are strikingly different from those in the contralateral kidney. Our results demonstrate that conductances of $\mathrm{Na}^{+}$and $\mathrm{K}^{+}$in the apical membrane, and electrogenic $\mathrm{Na}^{+}-\mathrm{K}^{+}$-ATPase pump activity and relative $\mathrm{K}^{+}$conductance in the basolateral membrane of the $\mathrm{CD}$ cell are decreased in the obstructed kidney, whereas they are increased in the contralateral kidney. We also found that the relative basolateral membrane $\mathrm{Cl}^{-}$conductance is increased in the obstructed kidney, and decreased in the contralateral kidney.

Electrical properties of the CD cell from the obstructed kidney. UUO is known to decrease the lumen-negative $\mathrm{V}_{\mathrm{T}}(6,8)$, lumen-to-bath ${ }^{22} \mathrm{Na}$ flux (6), and $\mathrm{Na}^{+}-\mathrm{K}^{+}$-ATPase activity (9) in the CCD from the obstructed kidney. However, whether either the $G_{A}$, the $G_{B}$, and/or the $G_{T j}$ is affected upon UUO, has not yet been determined. The present study showed that UUO selectively decreased the $G_{A}$ of the CD cell from the obstructed kidney.

$\mathrm{Na}^{+}$absorption in the CCD from normal rabbits is initiated by passive $\mathrm{Na}^{+}$diffusion from the lumen into the cell down its electrochemical gradient via $\mathrm{a} \mathrm{Na}^{+}$channel and is then actively extruded from the cell into the peritubular space via the $\mathrm{Na}^{+}$$\mathrm{K}^{+}$pump located in the basolateral membrane (10-13). In the present study, we observed that the amiloride-sensitive changes in $V_{A}, G_{T}$, and $f R_{A}$ were much lower in the $U U O_{O K}$ group. These observations indicate that the amiloride-sensitive $\mathrm{Na}^{+}$ conductance in the apical membrane of the $\mathrm{CD}$ cell from the obstructed kidney is inhibited upon UUO, resulting in a decrease in $\mathrm{Na}^{+}-\mathrm{K}^{+}$-ATPase activity. Such effects of UUO on the apical $\mathrm{Na}^{+}$conductance are consistent with the reported decrease in $\mathrm{Na}^{+}$reabsorption in the CCD from the obstructed rabbit kidney $4 \mathrm{~h}$ after UUO (6).

$\mathrm{K}^{+}$is secreted in the CCD from normal rabbits by a twostep process that involves uptake from the blood into the cell via the basolateral membrane $\mathrm{Na}^{+}-\mathrm{K}^{+}$pump and passive diffusion down the cell to the lumen through a large apical membrane $\mathrm{K}^{+}$conductive pathway (10-13). In the present study, 
Table VI. Effect of Ouabain in the Bath on Barrier Voltages and Conductances at the Initial Peak Response

\begin{tabular}{|c|c|c|c|c|}
\hline & $\mathbf{V}_{\mathbf{T}}$ & $\mathrm{v}_{\mathbf{B}}$ & $\mathrm{G}_{\mathrm{T}}$ & $\mathbf{f R}_{\mathrm{A}}$ \\
\hline & & & $\mathrm{mS} \cdot \mathrm{cm}^{-2}$ & \\
\hline \multicolumn{5}{|l|}{ Control } \\
\hline Without ouabain & $-8.8 \pm 1.8(7)$ & $-82.4 \pm 4.6(7)$ & $8.9 \pm 0.4(7)$ & $0.45 \pm 0.05(7)$ \\
\hline With ouabain & $0.4 \pm 1.2^{\S}(7)$ & $-71.7 \pm 4.6^{\S}(7)$ & $8.8 \pm 0.4(7)$ & $0.46 \pm 0.05(7)$ \\
\hline \multicolumn{5}{|l|}{$\mathrm{UUO}_{\mathrm{OK}}$} \\
\hline Without ouabain & $2.4 \pm 1.5(5)$ & $-62.4 \pm 0.9(5)$ & $4.3 \pm 0.7(5)$ & $0.53 \pm 0.05(5)$ \\
\hline With ouabain & $6.3 \pm 1.5^{*}(5)$ & $-57.8 \pm 1.3^{\ddagger}(5)$ & $4.2 \pm 0.7(5)$ & $0.54 \pm 0.05(5)$ \\
\hline \multicolumn{5}{|l|}{$\mathrm{UUO}_{\mathrm{CK}}$} \\
\hline Without ouabain & $-17.8 \pm 3.1(6)$ & $-91.3 \pm 1.5(6)$ & $10.4 \pm 1.1(6)$ & $0.37 \pm 0.07(6)$ \\
\hline With ouabain & $-3.2 \pm 2.0^{\S}(6)$ & $-67.5 \pm 2.7^{\S}(6)$ & $10.2 \pm 1.0(6)$ & $0.38 \pm 0.08(6)$ \\
\hline
\end{tabular}

Values are mean \pm SE. Data were obtained from the same experiments. Numerals in parentheses indicate number of experiments. ${ }^{*} P<0.01$, ${ }^{\ddagger} P<0.005,{ }^{\S} P<0.001$ compared to the preceding period.

we also demonstrate that the changes in $\mathrm{V}_{\mathrm{A}}$ and $\mathrm{G}_{\mathrm{T}}$ upon raising the luminal perfusate $\mathrm{K}^{+}$concentration and the changes in $V_{A}, G_{T}$ and $f R_{A}$ upon addition of luminal $\mathrm{Ba}^{2+}$ were much lower in the CCDs from the obstructed kidney. These findings are consistent with the notion that the $\mathrm{Ba}^{2+}$-sensitive $\mathrm{K}^{+}$conductance in the apical membrane of the $\mathrm{CD}$ cell from the obstructed kidney is also inhibited after UUO. Therefore, the impaired $\mathrm{K}^{+}$secretion in the CCD upon ureteral obstruction can be, at least in part, explained by a decrease in the apical membrane $\mathrm{K}^{+}$conductance.

In the obstructed tubule of the present study, the basolateral membrane of the CD cell depolarized by $\sim 15 \mathrm{mV}$ below the values of the control tubule. Furthermore, the initial pedk changes in $\mathrm{V}_{\mathbf{B}}$ upon addition of ouabain to the bath were lower in the $\mathrm{UUO}_{\mathrm{OK}}$ group, as shown in Fig. 5 and Table VI. From these two observations, it is concluded that the electrogenic $\mathrm{Na}^{+}-\mathrm{K}^{+}$pump activity in the basolateral membrane of the $\mathrm{CD}$ cell from the obstructed kidney is inhibited upon UUO. This decrease in basolateral $\mathrm{Na}^{+}-\mathrm{K}^{+}$pump activity is consistent with the reports that both the $\mathrm{Na}^{+}-\mathrm{K}^{+}-\mathrm{ATPase}$ activity $(9)$ and the $\mathrm{Na}^{+}-\mathrm{K}^{+}$pump in situ turnover (4) in the CCD of the obstructed rat kidney $24 \mathrm{~h}$ after UUO are decreased.

In the $\mathrm{CD}$ cell from normal rabbit kidneys, $\mathrm{K}^{+}$undergoes recycling across the basolateral membrane via active uptake by the $\mathrm{Na}^{+}-\mathrm{K}^{+}$pump and passive movement through a $\mathrm{K}^{+}$conductive pathway. The parallel coupling between the magnitude

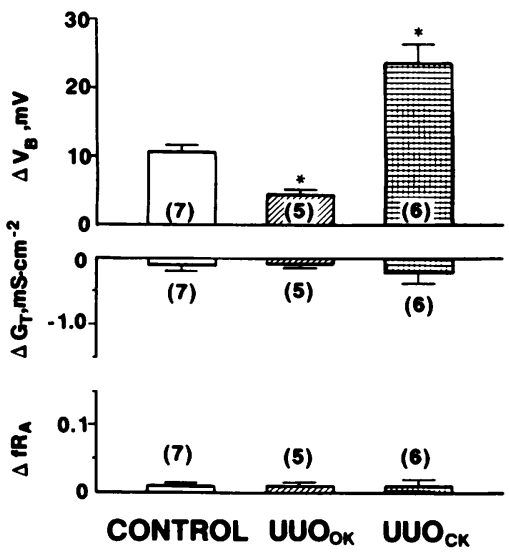

Figure 5. Comparison of the changes in $V_{B}$, $G_{T}$, and $f R_{A}$ upon addition of ouabain to the bath among the three groups. Values are mean \pm SE. Numerals in parentheses indicate number of experiments. ${ }^{*} P<0.001$ compared to control. of the $\mathrm{K}^{+}$conductive pathway at the basolateral membrane and the $\mathrm{Na}^{+}-\mathrm{K}^{+}$-ATPase pump activity exists in nearly all salttransporting epithelia: changes of the one component lead to respective alterations of the other. Thus, the relative $\mathrm{K}^{+}$conductance in the basolateral membrane would be expected to be inhibited upon UUO, because the basolateral $\mathrm{Na}^{+}-\mathrm{K}^{+}$pump activity is significantly decreased, as described above. Using the $\triangle \mathrm{EMF}$ upon abrupt changes in bath $\mathrm{K}^{+}$and $\mathrm{Cl}^{-}$concentrations, we can estimate the relative conductances of $\mathrm{K}^{+}$and $\mathrm{Cl}^{-}$ in the basolateral membrane. The present study demonstrates that the relative $\mathrm{K}^{+}$conductance is decreased, as was expected. In contrast to the $\mathrm{K}^{+}$conductance, the relative $\mathrm{Cl}^{-}$conductance is increased. However, this finding is not surprising. Greger et al. also reported that inhibition of $\mathrm{Na}^{+}-\mathrm{K}^{+}$-ATPase pump due to addition of ouabain caused an increase in $\mathrm{Cl}^{-}$ conductance and a decrease in $\mathrm{K}^{+}$conductance in rabbit cortical thick ascending limb (30) and in shark rectal gland (31). The reason why the relative $\mathrm{Cl}^{-}$conductance in the basolateral membrane of the CD cell from the obstructed kidney is increased, is not known at present. An inhibition of the $\mathrm{Na}^{+}-\mathrm{K}^{+}$ pump activity in parallel with decrease in basolateral $\mathrm{K}^{+}$conductance is associated with a depolarization of $V_{B}$, which might turn on a voltage-dependent $\mathrm{Cl}^{-}$conductance. In fact, as

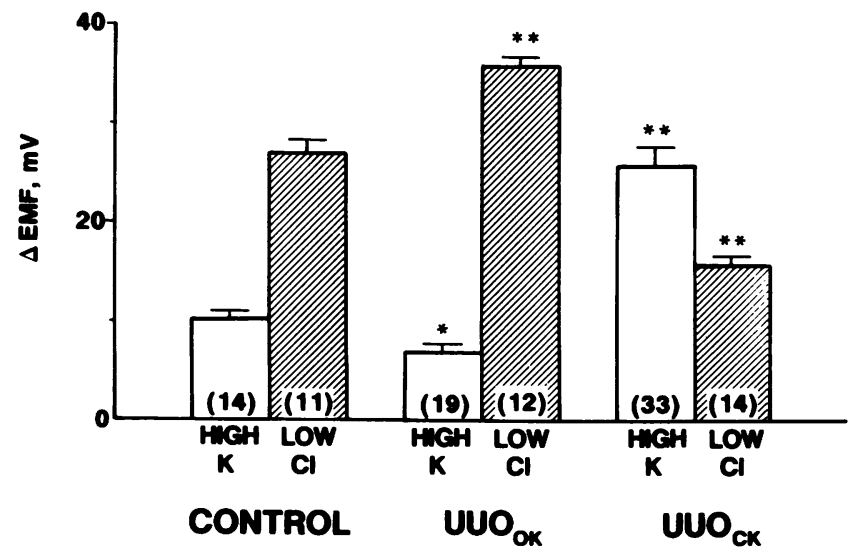

Figure 6. Comparison of the $\triangle \mathrm{EMF}$ upon raising bath $\mathrm{K}^{+}$concentration and lowering bath $\mathrm{Cl}^{-}$concentration among the three groups. Values are mean \pm SE. Numerals in parentheses indicate number of experiments. ${ }^{*} P<0.05,{ }^{* *} P<0.001$ compared to control. 


\begin{tabular}{|c|c|c|c|c|}
\hline & $\mathrm{v}_{\mathbf{T}}$ & $\mathrm{V}_{\mathbf{B}}$ & $\mathrm{G}_{\mathrm{T}}$ & $\mathbf{f R}_{\boldsymbol{A}}$ \\
\hline & & & $\mathrm{mS} \cdot \mathrm{cm}^{-2}$ & \\
\hline \multicolumn{5}{|l|}{ Control } \\
\hline $\mathrm{K}^{+} 5 \mathrm{mM}$ & $-8.0 \pm 1.9(14)$ & $-76.6 \pm 2.6(14)$ & $9.2 \pm 0.5(10)$ & $0.33 \pm 0.05(10)$ \\
\hline $\mathrm{K}^{+} 50 \mathrm{mM}$ & $3.0 \pm 1.7^{\ddagger}(14)$ & $-63.9 \pm 2.9^{\ddagger}(14)$ & $11.0 \pm 0.6^{*}(10)$ & $0.44 \pm 0.05 *(10)$ \\
\hline \multicolumn{5}{|l|}{$\mathrm{UUO}_{\mathrm{OK}}$} \\
\hline $\mathrm{K}^{+} 5 \mathrm{mM}$ & $2.3 \pm 0.8(19)$ & $-61.6 \pm 1.4(19)$ & $6.0 \pm 0.4(18)$ & $0.54 \pm 0.05(18)$ \\
\hline $\mathrm{K}^{+} 50 \mathrm{mM}$ & $8.6 \pm 1.2^{\ddagger}(19)$ & $-52.6 \pm 1.5^{\ddagger}(19)$ & $6.4 \pm 0.4^{\ddagger}(18)$ & $0.60 \pm 0.05^{\ddagger}(18)$ \\
\hline \multicolumn{5}{|l|}{$\mathrm{UUO}_{\mathrm{CK}}$} \\
\hline $\mathrm{K}^{+} 5 \mathrm{mM}$ & $-24.2 \pm 1.8(33)$ & $-96.6 \pm 1.6(33)$ & $10.9 \pm 0.5(28)$ & $0.36 \pm 0.03(28)$ \\
\hline $\mathrm{K}^{+} 50 \mathrm{mM}$ & $0.4 \pm 1.8^{\ddagger}(33)$ & $-67.1 \pm 1.6^{\ddagger}(33)$ & $14.7 \pm 0.7^{\ddagger}(28)$ & $0.53 \pm 0.03^{\ddagger}(28)$ \\
\hline
\end{tabular}

Values are mean \pm SE. Data were obtained from the same experiments. Numerals in parentheses indicate number of experiments. ${ }^{*} P<0.005$,

${ }^{\ddagger} P<0.001$ compared to the preceding period.

shown in Fig. 8, in both control and $\mathrm{UUO}_{\mathrm{OK}}$ groups of tubules, the $\triangle \mathrm{EMF}$ upon lowering bath $\mathrm{Cl}^{-}$concentration from 120 to $12.0 \mathrm{mM}$ was directly related to $\mathrm{V}_{\mathrm{B}}$. The relative $\mathrm{Cl}^{-}$conductance of the basolateral membrane is therefore greater in the $C D$ cell with lower $V_{B}$, regardless of ureteral obstruction. This direct correlation between $\mathrm{V}_{\mathrm{B}}$ and the relative $\mathrm{Cl}^{-}$conductance is also observed in the CD cell from normal and DOCA-treated rabbits (32). Sansom et al. (33) also reported that the $\mathrm{Cl}^{-}$ channel in the basolateral membrane of the CD cell from the normal rabbit was voltage-dependent at physiological potentials. Voltage dependent $\mathrm{Cl}^{-}$channels have also been reported in other epithelia (34-38) with patch champ technique. It is possible, therefore, that the decrease in basolateral $\mathrm{K}^{+}$conductance coupled with the inhibition of the $\mathrm{Na}^{+}-\mathrm{K}^{+}$pump is compensated by an increase in $\mathrm{Cl}^{-}$conductance, because the $\mathrm{G}_{\mathrm{B}}$ remains unchanged after UUO (Table II). More direct studies with $\mathrm{Cl}^{-}$-selective microelectrodes and patch-clamp techniques will be required to determine the intracellular $\mathrm{Cl}^{-}$activity and the relation between $\mathrm{V}_{\mathrm{B}}$, and basolateral $\mathrm{K}^{+}$and $\mathrm{Cl}^{-}$ conductances.
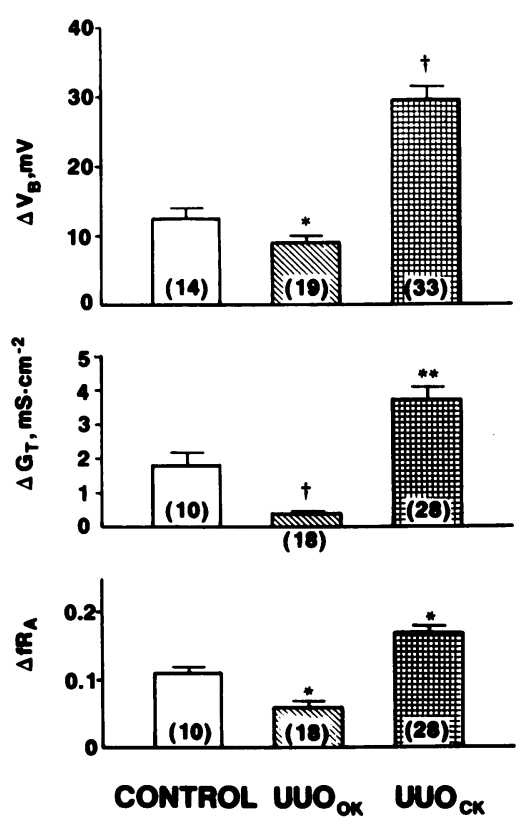

Figure 7. Comparison of the changes in $V_{B}$, $G_{T}$, and $f R_{A}$ upon raising bath $\mathrm{K}^{+}$concentration among the three groups. Values are mean \pm SE. Numerals in parentheses indicate number of experiments. ${ }^{*} P<0.05,{ }^{* *} P$ $<0.005,{ }^{\dagger} P<0.001$ compared to control.
The mechanisms responsible for the observed electrical changes of the apical as well as the basolateral membranes of the CD cell from the obstructed kidney after UUO are probably multifactorial. Although we have not yet determined them in the present study, we will only speculate some of them here in brief. Among the factors that might be operative singly or in concert, we might propose the consequences of luminal flow and pressure changes (1) and their influence on $\mathrm{Na}^{+}$and $\mathrm{K}^{+}$ transports in the CCD. According to Gross et al. (39), acute increase in intraluminal pressure in the rabbit $C C D$ perfused in vitro led to a rapid reduction in lumen-negative $\mathrm{V}_{\mathrm{T}}$, resulting in a decrease in $\mathrm{Na}^{+}$reabsorption. Therefore, if the rise in intraluminal pressure in vivo remained in the isolated perfused tubules from the obstructed kidney, it may possibly inhibit $\mathrm{Na}^{+}$entry into the cell at the apical border. This in turn would reduce the intracellular $\mathrm{Na}^{+}$activity, resulting in a decrease in $\mathrm{Na}^{+}-\mathrm{K}^{+}$-ATPase pump activity in the basolateral membrane. The low flow rate in the obstructed kidney may also be an important contributing factor to low $\mathrm{K}^{+}$secretion. This idea is also supported by the report of Engbretson and Stoner (40) that the linear relationship exists between $\mathrm{K}^{+}$secretion and perfusion rate between 5 and $6 \mathrm{nl} / \mathrm{min}$ in the rabbit CCD perfused in vitro.

Ureteral obstruction is known to stimulate the production of prostaglandins in the obstructed kidney $(41,42)$. In addition, in the CCD from normal rabbits, prostaglandins have been demonstrated to decrease $\mathrm{Na}^{+}$reabsorption $(43,44)$. Therefore, if increased production of prostaglandins in the obstructed kidney persists after isolation and during perfusion of the tubule, it may also contribute to decrease $\mathrm{Na}^{+}$reabsorption in the obstructed tubule. This idea is also supported by the report of Campbell et al. (6) that the reduced lumen-negative $V_{T}$ in the CCD from the obstructed rabbit kidney $4 \mathrm{~h}$ after UUO was prevented by pretreatment with indomethacin before the surgery. Further studies will be required to define the mechanisms of the electrical changes observed in the CD cell from the obstructed kidney.

Electrical properties of the $C D$ cell from the contralateral kidney. As described in Table II, the $\mathrm{G}_{\mathrm{A}}$ of the $\mathrm{CD}$ cell from the contralateral kidney appears to be also the influence of UUO. The $\mathrm{G}_{\mathrm{A}}$ in the $\mathrm{UUO}_{\mathrm{CK}}$ group was observed to increase by 2.4fold after UUO. Using changes in $V_{A}, G_{T}$, and $f R_{A}$ upon addition of luminal amiloride, upon raising luminal $\mathrm{K}^{+}$concentra- 
Table VIII. Effect of $2 \mathrm{mM} \mathrm{Ba} a^{+}$in the Bath on Barrier Voltages and Conductances at the Initial Peak Response

\begin{tabular}{|c|c|c|c|c|}
\hline & $\mathbf{V}_{\mathbf{T}}$ & $\mathrm{V}_{\mathrm{B}}$ & $\mathrm{G}_{\mathrm{T}}$ & $\mathrm{fR}_{\mathrm{A}}$ \\
\hline & & & $\mathrm{mS} \cdot \mathrm{cm}^{-2}$ & \\
\hline \multicolumn{5}{|l|}{ Control } \\
\hline Without $\mathrm{Ba}^{2+}$ & $-10.4 \pm 1.8(16)$ & $-77.5 \pm 2.3(16)$ & $8.9 \pm 0.4(10)$ & $0.49 \pm 0.06(10)$ \\
\hline With $\mathrm{Ba}^{2+}$ & $-11.2 \pm 2.4(16)$ & $-77.5 \pm 3.2(16)$ & $8.0 \pm 0.3^{*}(10)$ & $0.46 \pm 0.06^{*}(10)$ \\
\hline \multicolumn{5}{|l|}{$\mathrm{UUO}_{\mathrm{CK}}$} \\
\hline Without $\mathrm{Ba}^{2+}$ & $-22.2 \pm 1.4(20)$ & $-95.6 \pm 1.9(20)$ & $10.1 \pm 0.8(10)$ & $0.30 \pm 0.04(10)$ \\
\hline With $\mathrm{Ba}^{2+}$ & $-26.2 \pm 1.8 *(20)$ & $-99.8 \pm 2.3^{*}(20)$ & $8.4 \pm 0.8^{*}(10)$ & $0.19 \pm 0.03^{*}(10)$ \\
\hline
\end{tabular}

Values are mean \pm SE. Data were obtained from the same experiments. Numerals in parentheses indicate number of experiments. ${ }^{*} P<0.001$ compared to the preceding period.

tion and upon addition of luminal $\mathrm{Ba}^{2+}$, we can estimate the apical membrane $\mathrm{Na}^{+}$and $\mathrm{K}^{+}$conductances. As shown in Fig. 2 , the amiloride-sensitive $\mathrm{Na}^{+}$conductance in the apical membrane of the $\mathrm{CD}$ cell from the contralateral kidney is stimulated after UUO. Furthermore, as shown in Figs. 3 and 4, the changes in $V_{A}$ and $G_{T}$ upon raising the perfusate $K^{+}$concentration and upon addition of luminal $\mathrm{Ba}^{2+}$, were also much greater in the $\mathrm{UUO}_{\mathrm{CK}}$ group. These observations are consistent with the notion that the $\mathrm{Ba}^{2+}$-sensitive $\mathrm{K}^{+}$conductance in the apical membrane of the $\mathrm{CD}$ cell from the contralateral kidney is also stimulated upon UUO. The increased $\mathrm{Na}^{+}$and $\mathrm{K}^{+}$conductances in the apical membrane of the CD cell are also observed in the CCD from chronic DOCA-treated rabbits (29) and from the remnant kidneys in rabbits $14 \mathrm{~d}$ after UNX (25).

As illustrated in Fig. 1, the basolateral membrane of the CD cell in the $\mathrm{UUO}_{\mathrm{CK}}$ hyperpolarized by $\sim 20 \mathrm{mV}$ above the values in the control. Furthermore, the initial peak changes in $V_{B}$ upon addition of ouabain to the bath were significantly greater in the $\mathrm{UUO}_{\mathrm{CK}}$ group. From these two observations, it is indicated that the electrogenic $\mathrm{Na}^{+}-\mathrm{K}^{+}$pump activity in the basolateral membrane of the $\mathrm{CD}$ cell from the contralateral kidney is also stimulated after UUO.

As shown in Table II, the $G_{B}$ of the CD cell from the contralateral kidney were also affected by UUO. The $G_{B}$ of the CD cell had a 1.6-fold increase after UUO. Based on the $\triangle E M F$ upon abrupt changes in bath $\mathrm{K}^{+}$and $\mathrm{Cl}^{-}$concentrations, we demonstrate that the basolateral membrane of the $\mathrm{CD}$ cell in

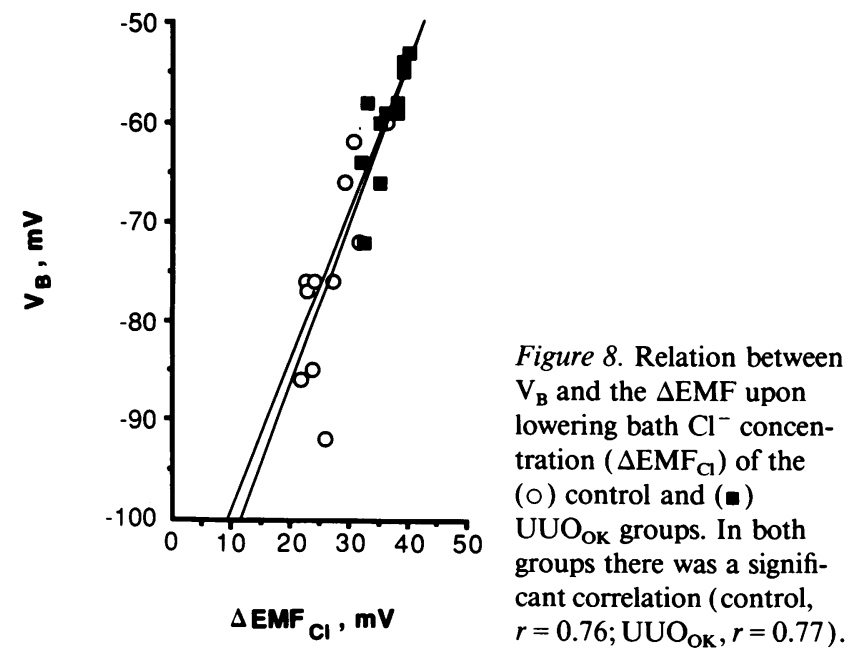

the CCDs from the contralateral kidney after UUO is predominantly selective to $\mathrm{K}^{+}$. These observations strikingly resemble those seen in the basolateral membrane of the CD cell in the CCD from chronic mineralocorticoid-treated rabbits $(29,32)$, and from remaining kidneys in rabbits $14 \mathrm{~d}$ after UNX (25).

In the $C D$ cell from normal rabbits, $V_{B}$ is known to be near the Nerst equilibrium potential for $\mathrm{K}^{+}$across the basolateral membrane $(25,29)$. In the present study, we also observed the same electrical property in the basolateral membrane of the $\mathrm{CD}$ cell from the control kidney, because $\mathrm{Ba}^{2+}$, an effective inhibitor of $\mathrm{K}^{+}$channel, to the bath had no effect on $\mathrm{V}_{\mathrm{B}}$. On the other hand, after UUO $-\mathrm{V}_{\mathrm{B}}$ in the $\mathrm{UUO}_{\mathrm{CK}}$ group was elevated by $\sim 20 \mathrm{mV}$ so that a driving force for $\mathrm{K}^{+}$entry into the cell could exist, because addition of $\mathrm{Ba}^{2+}$ to the bath caused the basolateral membrane to hyperpolarize significantly (Table VIII). Therefore, increases in both $\mathrm{K}^{+}$conductance and the driving force for $\mathrm{K}^{+}$across the basolateral membrane, could result in an increased $\mathrm{K}^{+}$uptake across the basolateral membrane in the CCDs from the contralateral kidney $24 \mathrm{~h}$ after UUO.

The mechanisms for the observed functional adaptations of the CD cell during the early stage of UUO remain unclear. Several factors, such as sodium delivery to the $\operatorname{CCD}(45,46)$ and mineralocorticoid (47), could be responsible for the adaptive increase in $\mathrm{Na}^{+}$and $\mathrm{K}^{+}$transports in the CCDs from the contralateral kidney. In addition, growth factors (17) may also be involved in the mechanisms of the adaptation after loss of functional nephron.

The present study demonstrates that both $\mathrm{Na}^{+}$and $\mathrm{K}^{+}$conductances in the apical membrane of the $\mathrm{CD}$ cell from the contralateral kidney are stimulated after UUO. However, both conductances do not increase in exact proportion. The $\mathrm{Na}^{+}$ conductance is increased to a greater degree than the $\mathrm{K}^{+}$conductance, because the amiloride-induced increase in $\mathrm{f}_{\mathrm{A}}$ is significantly greater in the $\mathrm{UUO}_{\mathrm{CK}}$ group than in the control group (Fig. 2), but the $\mathrm{Ba}^{2+}$-induced increase in $f \mathrm{R}_{\mathrm{A}}$ is not different between the two groups (Fig. 4). Thus, we propose that UUO leads to enhanced uptake of $\mathrm{Na}^{+}$into the CD cell across the apical membrane in the $\mathrm{CCD}$ from the contralateral kidney, and then to stimulate $\mathrm{Na}^{+}$absorption.

It should be noted that these functional adaptive changes were not associated with kidney and tubular hypertrophy in the present study. It has been demonstrated that the water absorption also in the isolated proximal straight tubule from the contralateral kidney in rabbits $24 \mathrm{~h}$ after UNX or UUO is increased, the despite the kidney weight is not greater than sham 
controls (48). The GFR in the UUO animals has been reported to increase even $24 \mathrm{~h}$ after UUO $(18,48)$. Accordingly, we speculate that an increased rate of $\mathrm{Na}^{+}$delivery to the CCD may result in an increase in the $\mathrm{Na}^{+}$uptake into the cell across the apical membrane, leading to a stimulation of kidney and tubular growth. Shirley and Walter (45) also arrived at the hypothesis that an increased rate of $\mathrm{Na}^{+}$delivery to the nephrons might act as a stimulus to kidney growth and/or to changes in tubular handling of electrolytes and water, because the changes in GFR and single nephron GFR in the remnant kidney in rats 2-5 $\mathrm{h}$ after UNX preceded any measurable change in kidney size. A close association between renal cell growth and dietary $\mathrm{Na}^{+}$intake has been reported in the renal tubules. Hypertrophy of proximal tubule cells is associated with a prolonged increase in $\mathrm{Na}^{+}$uptake $(49,50)$. An increase in the filtered load of $\mathrm{Na}^{+}$in the remnant nephrons stimulates the rate of cell $\mathrm{Na}^{+}$uptake via the apical membrane $\mathrm{Na}^{+}-\mathrm{H}^{+}$ antiporter, accelerates net $\mathrm{Na}^{+}$and water absorption, increases the quantity of $\mathrm{Na}^{+}-\mathrm{K}^{+}$-ATPase and enhances the area of the basolateral membrane in the proximal tubule $(50,51)$. A chronic rise in $\mathrm{Na}^{+}$absorption by segments of distal nephron is also associated with cellular hypertrophy and hyperplasia. Kaissling et al. (52-55) have reported that increased $\mathrm{Na}^{+}$delivery into the distal nephron by giving rats a high $\mathrm{Na}^{+}$diet and infusing furosemide, a diuretic that inhibits $\mathrm{Na}^{+}$and $\mathrm{Cl}^{-} \mathrm{ab}-$ sorption by the thick ascending limb, increased the $\mathrm{Na}^{+}$concentration in the tubular fluid, enhanced the electrochemical gradient promptly $\mathrm{Na}^{+}$influx across the apical membrane and stimulated $\mathrm{Na}^{+}$absorption by the distal tubule and CCD. These functional changes were paralleled with an increase in cell area, basolateral membrane area, and mitochondrial volume of the $\mathrm{Na}^{+}$-absorbing cells in the distal nephrons including distal convoluted tubule cells, connecting tubule cells, and $\mathrm{CD}$ cells. Further studies will be required to define the role of the $\mathrm{Na}^{+}$in compensatory renal hypertrophy.

In summary, we have clearly characterized the electrical properties of the $\mathrm{CD}$ cell from obstructed and contralateral kidneys after UUO.

\section{Acknowledgments}

We would like to thank Ms. H. Kasakura for expert secretarial assistance in preparing the manuscript.

This work was supported in part by a grant from the Japanese Kidney Foundation (Jinkenkyukai).

\section{References}

1. Klahr, S. 1983. Pathophysiology of obstructive nephropathy. Kidney Int. 23:414-426.

2. Bander, S. J., J. E. Buerkert, D. Martin, and S. Klahr. 1985. Long-term effects of 24-hr unilateral ureteral obstruction on renal function in the rat. Kidney Int. 28:614-620.

3. Thirakomen, K., N. Kozlov, J. A. L. Arruda, and N. A. Kurzman. 1976. Renal hydrogen ion secretion after release of unilateral ureteral obstructions. $\mathrm{Am}$. J. Physiol. 231:1233-1239.

4. Kimura, H., and S. K. Mujais. 1990. Cortical collecting duct Na-K pump in obstructive nephropathy. Am. J. Physiol. 258:F1320-F1327.

5. Batlle, D., J. A. L. Arruda, and N. A. Kurzman. 1981. Hyperkalemic distal renal tubular acidosis associated with obstructive uropathy. N. Engl. J. Med. 304:373-380.

6. Campbell, H. T., E. Bello-Reuss, and S. Klahr. 1985. Hydraulic water permeability and transepithelial voltage in the isolated perfused rabbit cortical collecting tubule following acute unilateral ureteral obstruction. J. Clin. Invest. 75:219-225.
7. Ribeiro, C., and W. N. Suki. 1986. Acidification in the medullary collecting duct following ureteral obstruction. Kidney Int. 29:1 167-1171.

8. Hanley, M. J., and K. Davidson. 1982. Isolated nephron segments from rabbit models of obstructive nephropathy. J. Clin. Invest. 69:165-174.

9. Sabatini, S., and N. A. Kurzman. 1990. Enzyme activity in obstructive uropathy: basis for salt wastage and the acidification defect. Kidney Int. 37:79-84.

10. Koeppen, B. M., B. A. Biagi, and G. H. Giebisch. 1982. Intracellular microelectrode characterization of the rabbit cortical collecting duct. Am. J. Physiol. 244:F35-F47.

11. O'Neil, R. G., and S. C. Sansom. 1984. Electrophysiological properties of cellular and paracellular conductive pathways of the rabbit cortical collecting duct. J. Membr. Biol. 82:281-295.

12. Muto, S., G. Giebisch, and S. Sansom. 1987. Effects of adrenalectomy on CCD: evidence for differential response of two cell types. Am. J. Physiol. 253:F742-F752.

13. Muto, S., S. Sansom, and G. Giebisch. 1987. Effects of high K diet on electrical properties of cortical collecting ducts from adrenalectomized rabbit. $J$. Clin. Invest. 81:376-380.

14. Muto, S., K. Yasoshima, K. Yoshitomi, M. Imai, and Y. Asano. 1990. Electrophysiological identification of $\alpha$ - and $\beta$-intercalated cells and their distribution along the rabbit distal nephron segments. J. Clin. Invest. 86:1829-1839.

15. Muto, S., H. Furuya, K. Tabei, and Y. Asano. 1991. Site and mechanism of action of epidermal growth factor in rabbit cortical collecting duct. Am. J. Physiol. 260:F163-F169.

16. Hayslett, J. P. 1979. Functional adaptation to reduction in renal mass. Physiol. Rev. 59:137-164.

17. Meyer, T. W., J. W. Scholey, and B. M. Brenner. 1991. Nephron adaptation to renal injury. In The Kidney 4th edition. B. M. Brenner and F. C. Rector, editors. W. B. Saunders Co., Philadelphia, PA. 1871-1908.

18. Dicker, S. E., and D. G. Shirley. 1992. Compensatory hypertrophy of the contralateral kidney after unilateral ureteral ligation. J. Physiol. (Lond.). 220:199-210.

19. Paulson, D. F., and E. E. Fraley. 1973. Compensatory renal growth after unilateral ureteral obstruction. Kidney Int. 4:22-27.

20. Chevalier, R. L., R. A. Gomez, and C. E. Jones. 1988. Developmental determinants of recovery after relief of partial ureteral obstruction. Kidney Int. 33:775-781.

21. Vehaskari, V. M., K. S. Hering-Smith, S. Klahr, and L. L. Hamm. 1989. Increased sodium transport by cortical collecting tubules from remnant kidneys. Kidney Int. 36:89-95.

22. Fine, L. G., N. Yanagawa, R. G. Schultze, M. Tuck, and W. Trizna. 1979. Functional profiles of the isolated uremic nephron: potassium adaptation in the rabbit cortical collecting tubule. J. Clin. Invest. 64:1033-1043.

23. Scherzer, P., H. Wald, and J. W. Czaczkes. 1985. Na-K-ATPase in isolated rabbit tubule after unilateral nephrectomy and $\mathrm{Na}^{+}$loading. Am. J. Physiol. 248:F565-F573.

24. Zalups, R. K., B. A. Stanton, J. W. Wade, and G. Giebisch. 1985. Structural adaptation in initial collecting tubule following reduction in renal mass. Kidney Int. 27:636-642.

25. Ebata, S., S. Muto, and Y. Asano. 1992. Effects of uninephrectomy on electrical properties of the cortical collecting duct from rabbit remnant kidneys. J. Clin. Invest. 90:1547-1557.

26. Burg, M. B., M. Grantham, S. Abramov, and J. Orloff. 1966. Preparation and study of fragments of single rabbit nephrons. Am. J. Physiol. 210:1293-1298.

27. Paulson, D. F., and E. E. Fraley. 1970. Chemical evidence for early but unsustained growth in the obstructed mouse kidney. Am. J. Physiol. 219:872875.

28. Shimamura, T., J. M. Kissane, and F. Gyorkey. 1966. Experimental hydronephrosis: nephron dissection and electron microscopy of the kidney following obstruction of the ureter and in recovery from obstruction. Lab. Invest. 15:629-640.

29. Sansom, S. C., and R. G. O'Neil. 1986. Effects of mineralocorticoids on transport properties of cortical collecting duct basolateral membrane. Am. J. Physiol. 251:F743-F757.

30. Greger, R., M. Wittner, E. Schlatter, and A. DiStefano. 1984. $\mathrm{Na}^{+}-2 \mathrm{Cl}-$ $\mathrm{K}^{+}$-cotransport in the thick ascending limb of Henle's loop and mechanism of action of loop diuretics. In Coupled Transport in Nephron. T. Hoshi, editor. Miura Foundation, Tokyo. 96-118.

31. Greger, R., and E. Schlatter. 1984. Mechanism of $\mathrm{NaCl}$ secretion in rectal gland tubules of spiny dogfish (Squalus acanthias). II. Effects of inhibitors. Pflügers Arch. Eur. J. Physiol. 402:364-375.

32. Sansom, S. C., S. Agulian, S. Muto, V. Illig, and G. Giebisch. 1989. K activity of CCD principal cells from normal and DOCA-treated rabbits. Am. J. Physiol. 256:F136-F142.

33. Sansom, S. C., B.-Q. La, and S. L. Carosi. 1990. Double-barreled chloride channels of collecting duct basolateral membrane. Am. J. Physiol. 259:F46-F52.

34. Nelson, D. J., J. M. Tang, and L. G. Palmer. 1984. Single-channel recordings of apical membrane chloride conductance in A6 epithelial cells. J. Membr. Biol. 80:81-89.

35. Evans, M. G., A. Marry, Y. P. Tan, and A. Trautmann. 1986. Blockage of 
Ca-activated $\mathrm{Cl}$ conductance by furosemide in rat lacrimal glands. Pflügers Arch. Eur. J. Physiol. 406:65-68.

36. Miller, C. 1982. Open-state substructure of single chloride channels from Torpedo electroplax. Philos. Trans. R. Soc. Lond. 299:401-411.

37. Halm, D. R., G. R. Rechkemmer, R. A. Schoumacher, and R. A. Frizzell. 1988. Apical membrane chloride channels in a colonic cell line activated by secretory agonists. Am. J. Physiol. 254:C505-C511.

38. Light, D. B., E. M. Schwiebert, G. Fejes-Toth, A. Naray-Fejes-Toth, K. H., Karlson, F. V. McCann, and B. A. Stanton. 1990. Chloride channels in the apical membrane of cortical collecting duct cells. Am. J. Physiol. 258:F273-F280.

39. Gross, J. B., M. Imai, and J. P. Kokko. 1975. A functional comparison of the cortical collecting tubule and the distal convoluted tubule. J. Clin. Invest. 55:1284-1294.

40. Engbretson, B. G., and L. C. Stoner. 1987. Flow-dependent potassium secretion by rabbit cortical collecting tubule in vitro. Am. J. Physiol. 253:F896F903.

41. Currie, M. G., B. B. Davis, and P. Needleman. 1981. Localization of exaggerated prostaglandin synthesis associated with renal damage. Prostaglandins. 22:933-944.

42. Whinnery, M. A., J. O. Shaw, and N. Beck. 1982. Thromboxane $B_{2}$ and prostaglandin $\mathrm{E}_{2}$ in the rat kidney with unilateral ureteral obstruction. Am. J. Physiol. 242:F220-F225.

43. Kokko, J. P. 1981. Effect of prostaglandins on renal epithelial electrolyte transport. Kidney Int. 19:791-796.

44. Holt, W. F., and C. Lechene. 1981. ADH-PGE 2 interactions in cortical collecting tubule. I. Depression of sodium transport. Am. J. Physiol. 241:F452F460.

45. Shirley, D. G., and S. J. Walter. 1991. Acute and chronic changes in renal function following unilateral nephrectomy. Kidney Int. 40:62-68.

46. Stanton, B. A., and B. Kaissling. 1989. Regulation of renal ion transport and cell growth by sodium. Am. J. Physiol. 257:F1-F10.
47. Vehaskari, V. M., and J. Herndon. 1991. Role of mineralocorticoids in adaptation of rabbit cortical collecting duct after loss of renal mass. Am. J. Physiol. 260:F793-F799.

48. Tabei, K., D. J. Levenson, and B. M. Brenner. 1983. Early enhancement of fluid transport in rabbit proximal stright tubules after loss of contralateral renal excretory function. J. Clin. Invest. 72:871-881.

49. Fine, L. G., B. Badie-Dezfooly, A. G. Lowe, A. Hamzeh, J. Wells, and S. Salehmoghaddam. 1985. Stimulation of $\mathrm{Na}^{+} / \mathrm{H}^{+}$antiport is an early event in hypertrophy of renal proximal tubule cells. Proc. Natl. Acad. Sci. USA. 82:17361740.

50. Salehmoghaddam, S., T. Bradley, N. Mikhail, B. Badie-Dezfooly, E. P. Nord, W. Trizna, R. Kheyfets, and L. G. Fine. 1985. Hypertrophy of basolateral Na-K pump activity in the proximal tubule of the remnant kidney. Lab. Invest. 53:443-452.

51. Salihagic, A., M. Mackovic, H. Banfic, and I. Saboic. 1988. Short-term and long-term stimulation of $\mathrm{Na}^{+}-\mathrm{H}^{+}$exchange in cortical brush-border membranes during compensatory growth of rat kidney. Pflügers Arch. Eur. J. Physiol. 413:190-196.

52. Kaissling, B., S. Bachmann, and W. Kriz. 1985. Structural adaptation of the distal convoluted tubule to prolonged furosemide treatment. Am. J. Physiol. 248:F374-F381.

53. Kaissling, B., and M. LeHir. 1982. Distal tubular segments of rabbit kidney after adaptation to altered $\mathrm{Na}$ - and $\mathrm{K}$-intake. I. Structural changes. Cell Tissue Res. 224:469-492.

54. Kaissling, B., and B. A. Stanton. 1988. Adaptation of distal tubule and collecting duct to increased sodium delivery. I. Ultrastructure. Am. J. Physiol. 255:F1256-F1268.

55. Stanton, B. A., and B. Kaissling. 1988. Adaptation of distal tubule and collecting duct to increased sodium delivery. II. $\mathrm{Na}^{+}$and $\mathrm{K}^{+}$transport. $A m$. J. Physiol. 255:F1269-F1275. 